\title{
Penggunaan Buku Ajar Nihongo Kirakira I pada Pembelajaran Bahasa Jepang di SMA Kesatrian I Semarang
}

\author{
The Usage of Nihongo Kirakira I Textbook for Japanese Language Learning \\ at Kesatrian I Semarang Senior High School
}

\author{
Nita Kusumawati ${ }^{1}$, Lispridona Diner ${ }^{2 *}$ \\ Universitas Negeri Semarang ${ }^{1,2}$ \\ xiipts.nitakusuma@gmail.com ${ }^{1}$ \\ lisjoost@yahoo.com ${ }^{2}$ \\ *corresponding author
}

\begin{abstract}
Nihongo Kirakira I is a textbook published by The Japan Foundation and compiled by following the Content Competencies and Basic Competencies of the 2013 curriculum for secondary education. This book has fulfilled the requirements of the Ministry of Education and Culture to answer the needs of basic level Japanese language learners, equivalent to the level 5 JLPT (Japanese Language Proficiency Test). Preliminary studies show that there are positive responses regarding to this book from students in Kesatrian 1 High School Semarang. This study aims to investigate the further responses about Japanese language learning by using Nihongo Kirakira I. This research was conducted by using quantitative descriptive methods, involving 72 respondents in Kesatrian High School 1. The data were obtained through open and closed questionnaires, then analyzed by using percentage descriptive techniques. The result shows that 42 respondents (58\%) gave "good" response and 30 respondents (42\%) gave "not good" response. Poor responses are caused by respondents' difficulty in pronouncing Japanese vocabulary and in reading hiragana and katakana letters. In general, respondents thought that learning Japanese using Nihongo Kirakira I is adequate.
\end{abstract}

Keywords: student responses, Japanese learning, Nihongo Kirakira I, descriptive, percentage

\section{INTISARI}

Nihongo Kirakira I merupakan buku ajar yang diterbitkan oleh The Japan Foundation dan disusun sesuai dengan Kompetensi Isi dan Kompetensi Dasar Kurikulum 2013 untuk pendidikan menengah. Buku ini telah memenuhi syarat dari Kementrian Pendidikan dan Kebudayaan guna menjawab kebutuhan peserta didik bahasa Jepang level dasar setara dengan JLPT (Japanese Language Proficiency Test) level 5. Studi pendahuluan di SMA Kesatrian 1 Semarang menunjukkan terdapat tanggapan positif dari siswa mengenai buku ini. Penelitian ini bertujuan mengetahui tanggapan lebih lanjut terhadap pembelajaran bahasa Jepang dengan menggunakan buku Nihongo Kirakira I. Penelitian dilakukan menggunakan metode deskriptif kuantitatif, melibatkan 72 responden di SMA Kesatrian 1. Data diperoleh melalui angket terbuka dan tertutup, dan dianalisis dengan teknik deskriptif persentase. Hasilnya, sebanyak 42 responden (58\%) beranggapan "baik" dan 30 responden (42\%) beranggapan "kurang baik". Tanggapan kurang baik disebabkan oleh kesulitan responden dalam melafalkan kosakata bahasa Jepang dan kesulitan dalam membaca huruf hiragana dan katakana. Secara umum tanggapan responden terhadap pembelajaran bahasa Jepang menggunakan buku Nihongo Kirakira I sudah baik.

Kata kunci: tanggapan siswa, pembelajaran bahasa Jepang, Nihongo Kirakira I, deskriptif, persentase

Panduan sitasi:

Kusumawati, N., Diner L. (2020). Penggunaan Buku Ajar Nihongo Kirakira I pada Pembelajaran Bahasa Jepang di SMA Kesatrian I Semarang. JLA (Jurnal Lingua Applicata), 4(1), 53-65 


\section{PENDAHULUAN}

The Japan Foundation Jakarta telah menyusun buku Nihongo Kirakira I dalam rangka mendukung pembelajaran bahasa Jepang di tingkat SMA. Buku Nihongo Kirakira I dibuat sesuai dengan kebutuhan pemelajar bahasa Jepang pada tingkat pemula. Buku tersebut ditulis berdasarkan hasil penelitian terkini mengenai pemerolehan bahasa kedua, sehingga isinya sesuai dengan tuntutan kurikulum pembelajaran bahasa Jepang dasar di Indonesia. Salah satu sekolah yang menggunakan buku Nihongo Kirakira I dalam pengajaran bahasa Jepang adalah SMA Kesatrian 1 Semarang.

Penggunaan buku Nihongo Kirakira

I di SMA Kesatrian 1 Semarang mendorong peneliti untuk mengetahui lebih jauh bagaimana tanggapan siswa selama mempelajari buku tersebut. Menurut Suryabrata (2010), tanggapan merupakan bayangan yang tinggal dalam ingatan setelah kita melakukan pengamatan. Dalam proses komunikasi, tanggapan tidak terjadi begitu saja, namun lahir melalui beberapa tahapan proses yang terjadi dalam diri seorang komunikan (penerima pesan). Proses ini merupakan komunikasi interpersonal yang terjadi untuk merespon stimulus. Stimulus yang diterima dari komunikator (pemberi pesan) kepada komunikan akan melalui proses pengenalan. Di tahap ini stimulus akan dikenali oleh komunikan yang kemudian dilanjutkan ke tahap penalaran dan perasaan. Pada tahap ini stimulus mengalami penalaran yaitu sebuah proses untuk menguji apakah stimulus tersebut diterima atau tidak. Proses ini melibatkan perasaan komunikan dalam memilih apakah rangsangan cocok dan diterima oleh dirinya. Jika stimulus cocok maka akan lahirlah tanggapan yang merupakan bentuk dari respon balik (feedback) atas stimulus yang diberikan (Effendy, 2017).

Tanggapan dalam pembelajaran bahasa Jepang mencakup unsur-unsur yang terkait dalam proses belajar, terdiri dari motivasi siswa, bahan belajar, alat bantu belajar, suasana belajar, dan kondisi subjek yang belajar (Haryanto, 2012). Proses pembelajaran merupakan proses komunikasi dua arah di mana terdapat kegiatan mengajar yang dilakukan oleh pihak guru sebagai pendidik dan kegiatan belajar yang dilakukan oleh peserta didik atau murid. Pembelajaran merupakan suatu proses atau kegiatan yang sistematis dan sistemik yang bersifat interaktif dan komunikatif antara pendidik (guru) dengan siswa, sumber belajar, dan lingkungan untuk menciptakan suatu kondisi yang memungkinkan terjadinya tindakan belajar siswa (Zainal, 2010). Dari uraian tersebut, dapat disimpulkan bahwa pembelajaran bahasa Jepang adalah proses pembekalan pengetahuan dan kemampuan dalam berbahasa Jepang dari guru kepada murid dengan bantuan sumber belajar berupa bahan ajar.

Penelitian terdahulu tentang bahan ajar telah dilakukan oleh Widyastuti (2017) dengan judul Tanggapan Siswa Kelas VII Terhadap Penggunaan Media Pembelajaran Dalam Pembelajaran 
Pendidikan Jasmani Olahraga dan Kesehatan di SMP Negeri 2 Pleret. Penelitian sejenis juga dilakukan oleh Palupi Putri Rahayu tahun 2019 dengan judul Analisis Nilai Karakter Yang Terdapat Dalam Buku Nihongo Kirakira 1, 2 Dan 3 (Rahayu, 2019). Perbedaan kedua penelitian tersebut dengan penelitian ini terdapat pada variabel bebas, populasi dan sampel yang digunakan.

Berdasarkan studi pendahuluan yang dilakukan di SMA Kesatrian 1 Semarang, diperoleh gambaran mengenai pembelajaran bahasa Jepang di sekolah tersebut. Berdasarkan hasil observasi, diketahui bahwa: (1) sebagian besar siswa mengikuti setiap alur pembelajaran dengan baik selama menggunakan buku Nihongo Kirakira I dalam pembelajaran bahasa Jepang; (2) banyak siswa yang mengikuti dan memperhatikan serta aktif selama pembelajaran berlangsung; namun (3) ada juga beberapa siswa yang terlihat bosan dan tidak mendengarkan.

Berdasarkan hasil observasi tersebut, diketahui bahwa selama menggunakan buku Nihongo Kirakira I dalam pembelajaran bahasa Jepang, sebagian besar siswa mengikuti setiap alur pembelajaran dengan baik. Meskipun demikian, tidak semua siswa aktif selama pembelajaran bahasa Jepang berlangsung. Beberapa siswa kelihatan bosan dan tidak menyimak dengan baik. Melalui observasi, Penulis menemukan bahwa kebosanan ini dialami siswa pada saat guru melakukan pengulangan audio berkali-kali. Pengulangan dilakukan dengan tujuan supaya siswa mudah mengingat kosakata yang diberikan. Menurut beberapa siswa, penggunaan media audio menimbulkan kebingungan pada siswa karena: (1) pelafalan yang terlalu cepat; (2) masih terdapat beberapa siswa yang tertinggal pada saat pelatihan kosakata dan percakapan; dan (3) banyak siswa yang tidak mendengarkan dan hanya mengisi jawaban lembar kerja semampunya atau tidak sesuai dengan ketentuan.

Dipandang dari proses pembelajaran, buku ajar mempunyai peranan penting. Jika tujuan pembelajaran adalah untuk menjadikan siswa memiliki berbagai kompetensi, maka perancangan buku ajar harus memperhatikan sejumlah komponen dalam pembelajaran. Komponen pembelajaran terdiri atas mahasiswa, pengajar atau pendidik, materi/bahan ajar, cara penyajian bahan ajar, dan latihan. Buku ajar yang baik adalah buku yang mencerminkan kesatuan yang padu atas seluruh komponen, mulai dari cara penyajian hingga pemberian latihan. Hal ini dimaksudkan supaya bahan ajar dengan mudah dipahami dan dipraktikkan, baik oleh mahasiswa maupun pengajar. (Kurniawan, 2012).

Menurut Prastowo (2014), fungsi bahan ajar bagi pengajar antara lain: (1) menghemat waktu guru dalam mengajar; (2) mengubah peran guru dari seorang pengajar menjadi seorang fasilitator; (3) meningkatkan proses pembelajaran menjadi lebih efektif dan interaktif; serta (4) menjadi alat evaluasi pencapaian atau penguasaan hasil pembelajaran. Adapun 
fungsi bahan ajar bagi peserta didik, antara lain: (1) peserta didik dapat belajar tanpa harus ada pengajar atau peserta didik lain; (2) peserta didik dapat belajar praktis kapan dan dimana saja; (3) dapat membantu potensi peserta didik menjadi mandiri dalam belajar; (4) berperan sebagai pedoman bagi peserta didik yang akan mengarahkan semua aktivitasnya dalam proses pembelajaran.

Bahan ajar dalam pembelajaran bahasa Jepang menjadi sangat penting karena di SMA 1 Kesatrian Semarang banyak siswa yang baru pertama kali mempelajari bahasa Jepang. Maka dari itu, penting untuk mengetahui tanggapan siswa terhadap pembelajaran bahasa Jepang menggunakan buku Nihongo Kirakira I.

\section{METODE PENELITIAN}

Penelitian ini menggunakan metode penelitian deskriptif kualitatif. Sumber data penelitian ini adalah jawaban angket dari siswa kelas XI SMA Kesatrian 1 Semarang yang diambil pada tahun 2019. Teknik pengumpulan data dalam penelitian ini menggunakan angket kombinasi terbuka dan tertutup. Angket penelitian berisi 30 butir pertanyaan. Bagian pertama terdiri dari 27 butir pertanyaan dengan pilihan jawaban tertutup, yaitu SL=Selalu, $\mathrm{S}=$ Sering, $\quad \mathrm{KK}=$ Kadang-kadang dan $\mathrm{TP}=$ Tidak Pernah. Bagian kedua terdiri dari tiga butir pertanyaan dengan jawaban esai bebas.

Terdapat empat indikator dalam angket penelitian ini, yaitu: (1) unsur-unsur belajar, yang dijabarkan dalam subindikator 1-4 (lihat tabel 2); (2) pembelajaran bahasa Jepang yang dijabarkan dalam subindikator 6-10 (lihat tabel 3); (3) buku Nihongo Kirakira I yang dijabarkan dalam subindikator 11-17 (lihat tabel 4); dan (4) tanggapan siswa SMA terhadap penggunaan buku Nihongo Kirakira $I$ yang dijabarkan dalam subindikator 18-20 (lihat tabel 5) dan subindikator 21-23 (lihat tabel 6).

\section{HASIL DAN PEMBAHASAN}

Untuk mengetahui penggolongan kelas dari hasil angket, maka diperlukan interval nilai yang dihitung berdasarkan rumus berikut (Sugiyono, 2016):

Persentase tertinggi:

$$
\frac{4}{4} \times 100 \%=100 \%
$$

Persentase terendah:

$$
\frac{1}{4} \times 100 \%=25 \%
$$

Rentang:

persentase tinggi - presentase rendah

$=100 \%-25 \%=75 \%$

Panjang kelas interval:

$$
\frac{75 \%}{4}=18,75 \%
$$

Berdasarkan hasil perhitungan tersebut, interval nilai setiap kelas sebesar 18,75\%. Rata-rata tanggapan siswa SMA Kesatrian I Semarang terhadap pembelajaran bahasa Jepang menggunakan buku Nihongo Kirakira I sebesar 65,72\%. Dengan demikian, kelas interval skor dapat dibagi ke dalam empat kategori (lihat Tabel $1)$. 
Tabel 1. Kelas Interval Skor

\begin{tabular}{cc}
\hline Interval Jumlah Skor & Kriteria \\
\hline $81,26 \%-100 \%$ & Sangat Tinggi \\
$62,51 \%-81,26 \%$ & Tinggi \\
$43,76 \%-62,51 \%$ & Rendah \\
$25 \%-43,76 \%$ & Sangat Rendah \\
\hline
\end{tabular}

Berdasarkan angket mengenai tanggapan responden pada buku Nihongo Kirakira I, hasil rata-rata skor secara keseluruhan menunjukkan kategori "tinggi". Data mengenai indikator unsur-unsur belajar (Tabel 2) menunjukkan bahwa:

1. Dorongan siswa untuk belajar menggunakan buku Nihongo Kirakira I" berada dalam kategori rendah. Hal ini juga ditunjukkan dengan persentase sebanyak $31 \%$ siswa yang menjawab “jarang” menggunakan buku Nihongo Kirakira I sebagai sumber belajar di rumah.

2. Isi dari buku mempermudah siswa ditunjukkan dalam kategori tinggi. Ini dibuktikan dengan persentase sebesar $39 \%$ siswa yang tidak merasa kesulitan belajar bahasa Jepang, karena dalam buku Nihongo Kirakira I sudah terdapat contoh kosa kata dan percakapan.

3. Media belajar yang digunakan pada buku Nihongo Kirakira I sangat membantu siswa dalam memahami percakapan bahasa Jepang karena tergolong dalam kategori yang tinggi. Dari 72 siswa, sebanyak $36 \%$ siswa dapat membuat percakapan sederhana dengan melihat contoh gambar pada buku Nihongo Kirakira I. Selain itu, sebanyak $42 \%$ siswa menjawab bahwa mereka dapat melakukan percakapan bahasa Jepang setelah mendengarkan audio yang diputar pada saat pembelajaran bahasa Jepang berlangsung. Oleh karena itu, dapat dikatakan media belajar yang terdapat dalam buku Nihongo Kirakira I dapat membantu siswa memahami pembelajaran bahasa Jepang.

4. Suasana kelas pada pembelajaran bahasa Jepang tidak mempengaruhi tingkat pemahaman siswa. Hal ini ditunjukkan dengan persentase sebesar $31 \%$ siswa menjawab "jarang”. Jawaban ini bermakna bahwa siswa tidak teralu keberatan belajar bahasa Jepang ketika kelas kotor dan gaduh. Sementara 39\% siswa yang menjawab "jarang", bermakna bahwa siswa tidak terlalu merasa bosan jika guru mengulang-ulang audio percakapan bahasa Jepang.

5. Minat siswa dalam belajar bahasa Jepang dan tingkat keaktifan siswa di dalam kelas pada saat pembelajaran bahasa Jepang berlangsung masih kurang. Hal tersebut ditunjukkan dengan persentase sebesar 49\% untuk jawaban "jarang" mengajukan diri, ketika guru meminta untuk mencontohkan percakapan di depan kelas. Selain itu hanya 39\% siswa yang mengatakan bahwa mereka bertanya kepada guru, ketika ada kosakata yang tidak diketahui. 
Tabel 2. Hasil Tanggapan Subindikator 1-5 untuk Indikator Unsur-Unsur Belajar

\begin{tabular}{|c|c|c|c|c|c|}
\hline & Subindikator & Pernyataan & B & $\mathbf{F}$ & $\mathbf{P}(\%)$ \\
\hline \multirow[t]{10}{*}{1.} & \multirow{10}{*}{$\begin{array}{l}\text { Siswa mendapatkan dorongan } \\
\text { untuk belajar bahasa Jepang } \\
\text { dari Buku Nihongo Kirakira I. }\end{array}$} & \multirow{5}{*}{$\begin{array}{l}\text { 1. Selain di sekolah, saya juga belajar } \\
\text { bahasa Jepang dengan menggunakan } \\
\text { buku Nihongo Kirakira I di rumah. }\end{array}$} & 4 & 21 & 29 \\
\hline & & & 3 & 19 & 26 \\
\hline & & & 2 & 22 & 31 \\
\hline & & & 1 & 10 & 14 \\
\hline & & & & 72 & 100 \\
\hline & & \multirow{5}{*}{$\begin{array}{l}\text { 2. Saya berlatih percakapan } \\
\text { menggunakan buku Nihongo Kirakira I } \\
\text { dengan teman sekelas sebelum } \\
\text { pembelajaran bahasa Jepang dimulai. }\end{array}$} & 4 & 1 & 1 \\
\hline & & & 3 & 5 & 7 \\
\hline & & & 2 & 32 & 44 \\
\hline & & & 1 & 34 & 47 \\
\hline & & & & 72 & 100 \\
\hline
\end{tabular}

2. Isi dari buku Nihongo Kirakira I mudah dipahami siswa.
3. Saya tidak merasa kesulitan belajar $4 \quad 20 \quad 28$ bahasa Jepang, karena dalam buku $3 \quad 28 \quad 39$ Nihongo Kirakira I sudah terdapat contoh $\quad 2 \quad 19 \quad 26$ kosa kata dan percakapan.
3. Media belajar yang terdapat dalam buku Nihongo Kirakira I dapat membantu siswa memahami pembelajaran bahasa Jepang.

4. Saya dapat melakukan percakapan $4 \quad 30 \quad 42$ bahasa Jepang dengan mendengarkan $3 \quad 18 \quad 25$ $\begin{array}{llllll}\text { audio yang diputar pada saat } 2 & 21 & 29\end{array}$ pembelajaran bahasa Jepang berlangsung. $\quad \begin{array}{lll}1 & 3 & 4\end{array}$

$72 \quad 100$

5. Saya dapat membuat percakapan $4 \quad 14 \quad 19$ sederhana dengan melihat contoh gambar $\quad 3 \quad 26 \quad 36$ $\begin{array}{llll}\text { pada buku Nihongo Kirakira I } & 2 & 24 & 33\end{array}$

$\begin{array}{rrr}1 & 8 & 11\end{array}$

$72 \quad 100$
4. Suasana kaat
pembelajaran berlangsung mempengaruhi tingkat pemahaman siswa.

6. Ketika kelas kotor dan gaduh pada saat $\quad 4 \quad 14 \quad 19$ pembelajaran bahasa Jepang berlangsung $\quad 3 \quad 16 \quad 22$ saya menjadi malas belajar bahasa $2 \quad 22$ Jepang.

$20 \quad 28$

$72 \quad 100$

7. Saya merasa bosan, ketika guru $4 \quad 48$ 11 $\begin{array}{lllll}\text { mengulang-ulang audio percakapan } & 3 & 12 & 17\end{array}$ bahasa Jepang.

5. Kondisi siswa pada saat pembelajaran bahasa Jepang berlangsung mempengaruhi tingkat pemahaman siswa.

8. Saya mengajukan diri, ketika guru $4 \quad 7 \quad 10$ $\begin{array}{lllll}\text { meminta untuk mencontohkan } & 3 & 9 & 13\end{array}$ percakapan di depan kelas.

$\begin{array}{rrr}2 & 35 & 49 \\ 1 & 21 & 29 \\ & 72 & 100\end{array}$

9. Saya bertanya kepada guru, ketika ada $\quad 4 \quad 17 \quad 24$ kosa kata yang tidak saya ketahui

\begin{tabular}{rrr}
4 & 17 & 24 \\
3 & 21 & 29 \\
\hline 2 & 27 & 38 \\
\hline 1 & 7 & 10 \\
& 72 & 100 \\
\hline
\end{tabular}

Sumber: Data Penelitian Penulis 
Tabel 3. Hasil Tanggapan Subindikator 6-10 untuk Indikator Pembelajaran Bahasa Jepang

\begin{tabular}{|c|c|c|c|c|}
\hline Subindikator & Pernyataan & B & $\mathbf{F}$ & $\mathbf{P}(\%)$ \\
\hline \multirow{5}{*}{$\begin{array}{l}\text { Guru mengenalkan } \\
\text { maeri yang akan } \\
\text { diajarkan pada hari ini. }\end{array}$} & \multirow{5}{*}{$\begin{array}{l}\text { 10. Guru meminta siswa untuk menyimak } \\
\text { gambar/video percakapan sebelum pembelajaran } \\
\text { bahasa Jepang berlangsung. }\end{array}$} & 4 & 34 & 29 \\
\hline & & 3 & 26 & 36 \\
\hline & & 2 & 9 & 13 \\
\hline & & 1 & 3 & 4 \\
\hline & & & 72 & 100 \\
\hline \multirow{10}{*}{$\begin{array}{l}\text { Guru meminta siswa } \\
\text { untuk berdiskusi tentang } \\
\text { materi bahasa Jepang } \\
\text { yang akan mereka } \\
\text { pelajari }\end{array}$} & \multirow{5}{*}{$\begin{array}{l}\text { 11. Guru meminta pendapat tentang materi apa } \\
\text { yang akan mereka pelajari. }\end{array}$} & 4 & 20 & 28 \\
\hline & & 3 & 34 & 47 \\
\hline & & 2 & 14 & 19 \\
\hline & & 1 & 4 & 6 \\
\hline & & & 72 & 100 \\
\hline & \multirow{5}{*}{$\begin{array}{l}\text { 12. Guru melakukan tanya jawab dengan siswa } \\
\text { berhubungan dengan pembelajaran bahasa } \\
\text { Jepang yang akan mereka pelajari. }\end{array}$} & 4 & 32 & 44 \\
\hline & & 3 & 26 & 36 \\
\hline & & 2 & 10 & 14 \\
\hline & & 1 & 4 & 6 \\
\hline & & & 72 & 100 \\
\hline \multirow{5}{*}{$\begin{array}{l}\text { 8. Guru memberikan } \\
\text { contoh materi bahasa } \\
\text { Jepang yang akan } \\
\text { dipelajari }\end{array}$} & \multirow{5}{*}{$\begin{array}{l}\text { 13. Guru mencontohkan percakapan bahasa } \\
\text { Jepang yang sedang dipelajari. }\end{array}$} & 4 & 46 & 64 \\
\hline & & 3 & 18 & 25 \\
\hline & & 2 & 6 & 8 \\
\hline & & 1 & 2 & 3 \\
\hline & & & 72 & 100 \\
\hline \multirow{5}{*}{$\begin{array}{l}\text { 9. Guru meminta siswa } \\
\text { untuk membuat } \\
\text { percakapan dalam } \\
\text { bahasa Jepang sendiri. }\end{array}$} & \multirow{5}{*}{$\begin{array}{l}\text { 14. Guru memberikan kesempatan kepada siswa } \\
\text { untuk maju menggunakan perckapan bahasa } \\
\text { Jepang dengan teman sekelas. }\end{array}$} & 4 & 30 & 42 \\
\hline & & 3 & 26 & 36 \\
\hline & & 2 & 13 & 18 \\
\hline & & 1 & 3 & 4 \\
\hline & & & 72 & 100 \\
\hline \multirow{5}{*}{$\begin{array}{l}\text { 10. Guru memberikan } \\
\text { kesempatan pada siswa } \\
\text { untuk bertanya }\end{array}$} & \multirow{5}{*}{$\begin{array}{l}\text { 15. Guru memberikan kesempatan siswa } \\
\text { bertanya setelah pembelajaran bahasa Jepang } \\
\text { selesai. }\end{array}$} & 4 & 32 & 44 \\
\hline & & 3 & 25 & 35 \\
\hline & & 2 & 11 & 15 \\
\hline & & 1 & 4 & 6 \\
\hline & & & 72 & 100 \\
\hline
\end{tabular}

\section{Sumber: Data Penelitian Penulis}

Hasil perhitungan persentase tanggapan siswa pada indikator pembelajaran bahasa Jepang dapat dilihat pada tabel 3. Berdasarkan tabel 3, jawaban untuk semua subindikator berada pada kategori 3 dan 4. Dengan demikian dapat disimpulkan bahwa pembelajaran bahasa Jepang yang dilaksanakan guru dalam kategori baik. Hal ini ditunjukkan melalui analisis sebagai berikut:

1. Sebanyak $36 \%$ siswa menjawab bahwa guru "sering" meminta siswa untuk menyimak gambar/video percakapan sebelum pembelajaran bahasa Jepang dimulai. Hal ini menunjukkan bahwa sebelum pembelajaran dimulai, sebelumnya guru telah memperkenalkan materi yang akan diajarkan. 
2. Sebanyak 47\% siswa menjawab "sering" diminta berpendapat mengenai materi yang akan dipelajari. Pada poin pernyataan selanjutnya, sebanyak $44 \%$ siswa menjawab "selalu" melakukan tanya jawab dengan guru mengenai pembelajaran bahasa Jepang yang akan mereka pelajari. Ini menunjukkan dalam pembelajaran bahasa Jepang menggunakan buku Nihongo Kirakira I, guru meminta siswa untuk berdiskusi tentang materi bahasa Jepang yang akan mereka pelajari.

3. Sebanyak $64 \%$ siswa menyatakan bahwa guru selalu mencontohkan percakapan bahasa Jepang yang sedang dipelajari. Oleh karena itu, dapat dikatakan bahwa guru mempraktikkan materi percakapan dari buku Nihongo Kirakira I untuk dapat ditirukan oleh siswa.

4. Sebanyak $42 \%$ siswa menyatakan bahwa guru "selalu" memberikan kesempatan kepada siswa untuk maju menggunakan percakapan bahasa Jepang dengan teman sekelas. Hal ini mengindikasikan bahwa dalam proses pembelajaran bahasa Jepang dengan buku Nihongo Kirakira I guru meminta siswa untuk membuat percakapan dalam bahasa Jepang sendiri.

5. Sebanyak $44 \%$ siswa menyatakan bahwa guru "selalu" memberikan kesempatan siswa bertanya setelah pembelajaran bahasa Jepang selesai. Ini menunjukkan bahwa dalam proses pembelajaran menggunakan buku Nihongo Kirakira I, siswa dapat bertanya kepada guru mengenai pembelajaran bahasa Jepang.
Selanjutnya, pada tabel 4 ditunjukkan perhitungan persentase tanggapan responden terhadap indikator buku Nihongo Kirakira I. :

1. Sebanyak $35 \%$ siswa menjawab bahwa buku Nihongo Kirakira I "jarang" membantu memberikan gambaran materi bahasa Jepang yang akan dipelajari. Oleh karena itu, disimpulkan bahwa kegiatan mite kangaemashou tidak terlalu membantu siswa untuk fokus pada materi pembelajaran bahasa Jepang.

2. Sebanyak $43 \%$ siswa menjawab "selalu" untuk pernyataan bahwa buku Nihongo Kirakira I mempermudah dalam menghafalkan kosa kata bahasa Jepang. Dari sini dapat disimpulkan bahwa pada sesi kegiatan kiite iimashou siswa terbantu dalam mempelajari kosa kata bahasa Jepang.

3. Sebanyak $38 \%$ siswa menjawab "tidak pernah" mengalami kesulitan dalam melafalkan kosa kata percakapan dalam bahasa Jepang. Dengan demikian, disimpulkan bahwa kegiatan nihongo de iimashou membantu siswa dalam mempelajari pelafalan kosa kata bahasa Jepang.

4. Sebanyak $38 \%$ siswa menyatakan bahwa mereka "selalu" dapat menjawab soal dengan benar setelah mendengarkan materi audio dari buku Nihongo Kirakira I. Oleh karena itu dapat disimpulkan bahwa pada sesi kegiatan kikimashou, siswa merasa terbantu dalam mempelajari kosa kata bahasa Jepang setelah mendengarkan rekaman suara dari penutur asli. 
Tabel 4. Hasil Tanggapan Subindikator 11-17 untuk Indikator Buku Nihongo Kirakira I

\begin{tabular}{llrrrr}
\hline \multicolumn{2}{c}{ Subindikator } & Pernyataan & B & F & $\begin{array}{r}\text { P } \\
(\%)\end{array}$ \\
\hline 11. Pada saat kegiatan mite & 16. Buku Nihongo Kirakira I membantu saya & 4 & 24 & 33 \\
kangaemashou membantu & memiliki gambaran tentang materi bahasa & 3 & 16 & 22 \\
siswa untuk fokus pada & Jepang apa yang akan dipelajari. & 2 & 25 & 35 \\
materi pembelajaran bahasa & & 1 & 7 & 10 \\
Jepang. & & & 72 & 100 \\
\hline
\end{tabular}

13. Pada saat kegiatan nihongo de iimashou dapat melatih siswa dalam penyebutan kosa kata bahasa Jepang
18. Saya kesulitan melafalkan kosa kata $4 \quad 4 \quad 6 \quad 8$ $\begin{array}{llll}\text { percakapan dalam bahasa Jepang. } & 3 & 21 & 29\end{array}$

$2 \quad 18 \quad 25$

$72 \quad 100$

14. Pada saat kegiatan 19. Saya dapat menjawab soal yang terdapat kikimashou siswa dapat mengenal kosa kata bahasa Jepang dengan mendengarkan audio dari pada buku Nihongo Kirakira I, setelah mendengarkan audio percakapan bahasa Jepang. penutur bahasa Jepang.

\begin{tabular}{rrr}
4 & 22 & 31 \\
3 & 27 & 38 \\
2 & 18 & 25 \\
1 & 5 & 7 \\
& 72 & 100 \\
\hline
\end{tabular}

15. Pada saat kegiatan hanashimashou dapat melatih siswa melakukan percakapan sederhana 20. Saya bisa melakukan percakapan sederhana $\quad \begin{array}{lll}4 & 13 & 18\end{array}$ menggunakan bahasa Jepang dengan teman $\begin{array}{llll}3 & 29 & 40\end{array}$ menggunakan bahasa Jepang. sekelas saya..

$\begin{array}{rrr}2 & 21 & 29 \\ 1 & 9 & 13\end{array}$

$72 \quad 100$

16. Pada saat kegiatan 21. Saya kesulitan membaca kosa kata bahasa yomimashou siswa dapat Jepang dalam huruf Jepang. mengidentifikasikan huruf bahasa Jepang.

\begin{tabular}{rrr}
4 & 19 & 26 \\
3 & 31 & 28 \\
2 & 20 & 28 \\
1 & 2 & 3 \\
& 72 & 100 \\
\hline
\end{tabular}

17. Pada saat kegiatan renshuu shimashou siswa dapat berlatih secara mandiri kemampuan bahasa Jepang yang sudah dipelajari.
22. Setelah pembelajaran bahasa Jepang berakhir $\quad 4 \quad 4 \quad 11$ saya bisa berlatih soal dan percakapan bahasa $\begin{array}{llll}3 & 15 & 21\end{array}$ Jepang sendiri dengan menggunakan buku $\begin{array}{llll}2 & 30 & 42\end{array}$ Nihongo Kirakira I

\section{Sumber: Data Penelitian Penulis}

5. Sebanyak $40 \%$ siswa menyatakan bahwa mereka mampu melakukan percakapan sederhana menggunakan bahasa Jepang dengan teman sekelas. Dari sini disimpulkan bahwa sesi kegiatan hanashimashou dapat melatih siswa melakukan percakapan sederhana menggunakan bahasa Jepang.

6. Sebanyak $28 \%$ responden memilih "selalu" mengalami kesulitan membaca kosa kata bahasa Jepang dalam huruf Jepang. Maka disimpulkan bahwa 
kegiatan yomimashou belum efektif bagi pembelajaran bahasa Jepang, karena siswa belum lancar dalam menggunakan huruf hiragana dan katakana.

7. Sebanyak $42 \%$ siswa menjawab bahwa setelah pembelajaran berakhir, mereka "jarang" berlatih mandiri dengan mengerjakan soal-soal yang ada dalam buku Nihongo Kirakira I. Maka dari itu dapat disimpulkan bahwa kegiatan renshuu shimashou masih belum efektif untuk melatih kemampuan siswa secara mandiri di luar kelas.

Berdasarkan tabel 4 subindikator 12,

14, 15, dan 16 disimpulkan bahwa tanggapan responden untuk indikator buku Nihongo Kirakira I sudah baik. Sementara persentase subindikator yang masih rendah yaitu:

1. Subindikator 11, yakni pada saat kegiatan mite kangaemashou yang diharapkan membantu siswa untuk fokus pada materi pembelajaran bahasa Jepang.

2. Subindikator 13, yaitu pada saat kegiatan nihongo de iimashou yang diharapkan dapat melatih siswa dalam penyebutan kosakata bahasa Jepang.

3. Subindikator 17, yaitu pada saat kegiatan renshuu shimashou yakni pada bagian siswa diharapkan dapat berlatih secara mandiri kemampuan bahasa Jepang yang sudah dipelajari.

Hasil perhitungan persentase pada indikator pembelajaran bahasa jepang untuk butir pilihan jawaban yang terdiri dari subindikator 18-20 dapat dilihat pada tabel 5. Berdasarkan tabel 5, semua jawaban berada pada kategori rendah, yang menunjukkan bahwa buku Nihongo Kirakira I:

1. Belum meningkatkan kemampuan berbahasa Jepang secara maksimal. Pernyataan ini ditunjukkan dengan persentase jawaban sebanyak 54\% siswa "tidak pernah" berlatih bahasa Jepang dengan teman sekelas di luar jam pembelajaran bahasa Jepang di kelas.

2. Belum meningkatkan rasa ingin tahu siswa terhadap bahasa Jepang dan budaya Jepang. Hal tersebut ditunjukkan dengan sebanyak $51 \%$ siswa menyatakan "tidak pernah" menonton anime (kartun Jepang) setelah belajar bahasa Jepang di sekolah. Serta persentase $61 \%$ untuk siswa yang menjawab "tidak pernah" mendengarkan musik dalam bahasa Jepang setelah saya belajar bahasa Jepang di sekolah.

3. Kurang membantu mengembangkan kreatifitas siswa dalam belajar bahasa Jepang. Hal ini ditunjukkan dengan persentase sebesar $31 \%$ untuk siswa yang menyatakan bahwa mereka senang karena dengan mengerjakan proyek yang diberikan dalam kelas bahasa Jepang, mereka menjadi lebih kreatif.

Dengan demikian, dapat disimpulkan bahwa jawaban negatif muncul karena Buku Nihongo Kirakira I masih bersifat media pembelajaran satu arah yang belum dapat memicu semangat siswa untuk belajar mandiri. Di sini dapat dilihat bahwa untuk mempelajari bahasa Jepang secara intensif, dibutuhkan keinginan dan motivasi dari siswa sendiri untuk mempelajari. Sebagai solusi, pada 
pembelajaran dapat dibantu dengan media seperti slide presentasi dalam power point dua arah yang melibatkan visual dan audio, dan cuplikan media berbahasa Jepang.

Tabel 5 Hasil Tanggapan Subindikator 18-20 untuk Indikator Buku Nihongo Kirakira I.

\begin{tabular}{|c|c|c|c|c|c|}
\hline & Subindikator & Pernyataan & B & $\mathbf{F}$ & $\mathbf{P}(\%)$ \\
\hline \multirow[t]{10}{*}{18.} & Buku Nihongo & 23. Di luar jam pembelajaran bahasa Jepang saya & 4 & 1 & 1 \\
\hline & \multirow{9}{*}{$\begin{array}{l}\text { Kirakira I } \\
\text { meningkatkan } \\
\text { kemampuan } \\
\text { berbahasa Jepang }\end{array}$} & \multirow[t]{4}{*}{ berlatih bahasa Jepang dengan teman sekelas saya. } & 3 & 4 & 6 \\
\hline & & & 2 & 28 & 39 \\
\hline & & & 1 & 39 & 54 \\
\hline & & & & 72 & 100 \\
\hline & & \multirow{5}{*}{$\begin{array}{l}\text { 24. Ketika ada orang Jepang berkunjung ke sekolah, } \\
\text { saya bisa melakukan percakapan sederhana dengan } \\
\text { bahasa Jepang. }\end{array}$} & 4 & 7 & 10 \\
\hline & & & 3 & 8 & 11 \\
\hline & & & 2 & 28 & 39 \\
\hline & & & 1 & 29 & 40 \\
\hline & & & & 72 & 100 \\
\hline \multirow[t]{10}{*}{19.} & \multirow{10}{*}{$\begin{array}{l}\text { Buku Nihongo } \\
\text { Kirakira I rasa } \\
\text { ingin tahu siswa } \\
\text { terhadap bahasa } \\
\text { Jepang dan budaya } \\
\text { Jepang }\end{array}$} & \multirow{5}{*}{$\begin{array}{l}\text { 25. Saya suka menonton anime (kartun Jepang) } \\
\text { setelah saya belajar bahasa Jepang di sekolah. }\end{array}$} & 4 & 8 & 11 \\
\hline & & & 3 & 11 & 15 \\
\hline & & & 2 & 16 & 22 \\
\hline & & & 1 & 37 & 51 \\
\hline & & & & 72 & 100 \\
\hline & & \multirow{5}{*}{$\begin{array}{l}\text { 26. Saya suka mendengarkan musik dalam bahasa } \\
\text { Jepang setelah saya belajar bahasa Jepang di sekolah }\end{array}$} & 4 & 6 & 8 \\
\hline & & & 3 & 3 & 4 \\
\hline & & & 2 & 19 & 26 \\
\hline & & & 1 & 44 & 61 \\
\hline & & & & 72 & 100 \\
\hline \multirow[t]{6}{*}{20.} & \multirow{6}{*}{$\begin{array}{l}\text { Buku Nihongo } \\
\text { Kirakira I } \\
\text { membantu } \\
\text { mengembangkan } \\
\text { kreatifitas siswa } \\
\text { dalam belajar } \\
\text { bahasa Jepang. }\end{array}$} & \multirow{6}{*}{$\begin{array}{l}\text { 27. Saya senang bisa belajar bahasa Jepang karena } \\
\text { dapat membantu saya lebih kreatif dengan tugas } \\
\text { membuat prakarya proyek yang diberikan. }\end{array}$} & 4 & 21 & 29 \\
\hline & & & 3 & 19 & 26 \\
\hline & & & 2 & 22 & 31 \\
\hline & & & 1 & 10 & 14 \\
\hline & & & & & \\
\hline & & & & 72 & 100 \\
\hline
\end{tabular}

\section{Sumber: Data Penelitian Penulis}

Selanjunya, pada tabel 6 ditunjukkan hasil perhitungan persentase untuk indikator pembelajaran bahasa Jepang. Butir pilihan jawaban yang terdiri dari subindikator 21-23 menunjukkan jawaban positif. Berdasarkan hal tersebut, maka dapat disimpulkan bahwa buku Nihongo Kirakira I:

1. Dapat membantu siswa menemukan minatnya belajar bahasa Jepang. Hal ini ditunjukkan dengan persentase sebesar
$64 \%$ untuk siswa yang menyatakan bahwa setelah belajar bahasa Jepang menggunakan buku Nihongo Kirakira I, muncul keinginan untuk mempelajari bahasa Jepang lebih lanjut.

2. Mempermudah siswa menguasai materi belajar Bahasa Jepang. Ini ditunjukkan dengan sebesar $92 \%$ siswa menyatakan bahwa buku Nihongo Kirakira I menunjang pembelajaran bahasa Jepang baik di rumah maupun di sekolah. 
Tabel 6 Hasil Tanggapan Subindikator 21-23 Untuk Indikator Buku Nihongo Kirakira I

\begin{tabular}{|c|c|c|c|c|}
\hline Subindikator & Pernyataan & Jawaban & $\mathbf{X}$ & $\mathbf{P}(\%)$ \\
\hline $\begin{array}{l}\text { 21. Buku Nihongo Kirakira I dapat } \\
\text { membantu siswa menemukan } \\
\text { minatnya belajar bahasa } \\
\text { Jepang. }\end{array}$ & $\begin{array}{l}\text { 28. Buku Nihongo Kirakira I } \\
\text { menambah minat saya untuk belajar } \\
\text { bahasa Jepang lebih lanjut. }\end{array}$ & $\begin{array}{l}\text { YA } \\
\text { TIDAK }\end{array}$ & $\begin{array}{l}64 \\
8 \\
72\end{array}$ & $\begin{array}{l}89 \\
11 \\
100\end{array}$ \\
\hline $\begin{array}{l}\text { 22. Buku Nihongo Kirakira I } \\
\text { mempermudah } \\
\text { menguasai materi belajar } \\
\text { bahasa Jepang. }\end{array}$ & $\begin{array}{l}\text { 29. Buku Nihongo Kirakira I } \\
\text { mempermudah saya belajar bahasa } \\
\text { Jepang di sekolah maupun di rumah. }\end{array}$ & $\begin{array}{l}\text { YA } \\
\text { TIDAK }\end{array}$ & $\begin{array}{l}66 \\
6 \\
72\end{array}$ & $\begin{array}{l}92 \\
8 \\
100\end{array}$ \\
\hline $\begin{array}{l}\text { 23. Buku Nihongo Kirakira I } \\
\text { membantu siswa aktif di dalam } \\
\text { kelas. }\end{array}$ & $\begin{array}{l}\text { 30. Buku Nihongo Kirakira I } \\
\text { membuat saya aktif di dalam kelas } \\
\text { selama pembelajaran bahasa Jepang } \\
\text { berlangsung. }\end{array}$ & $\begin{array}{l}\text { YA } \\
\text { TIDAK }\end{array}$ & $\begin{array}{l}66 \\
6 \\
72\end{array}$ & $\begin{array}{l}92 \\
8 \\
100\end{array}$ \\
\hline
\end{tabular}

\section{Sumber: Data Penelitian Penulis}

3. Membantu siswa aktif di dalam kelas. Hal ini dibuktikan dengan persentase sebesar $92 \%$ untuk siswa yang menyatakan bahwa penggunaan buku Nihongo Kirakira I membuat mereka aktif di kelas. Aktif di sini merujuk pada kegiatan pembelajaran bahasa Jepang menggunakan buku Nihongo Kirakira I telah berhasil membuat siswa berbicara, mendengar, dan membaca selama proses pembelajaran bahasa Jepang berlangsung.

\section{KESIMPULAN}

Pembelajaran bahasa Jepang di SMA Kesatrian I Semarang sudah tergolong baik dan sesuai dengan alur pembelajaran bahasa Jepang yang disusun oleh Japan Foundation. Hal ini didukung dengan penyesuaian alur pembelajaran dari Japan Foundation dengan kurikulum 2013 yang berlaku di Indonesia. Berdasarkan hasil pengolahan data angket dan analisisnya, dapat disimpulkan bahwa dengan menggunakan buku Nihongo
Kirakira I, siswa dapat lebih mudah belajar bahasa Jepang di sekolah.

Buku Nihongo Kirakira I membantu siswa menjadi lebih aktif selama pembelajaran bahasa Jepang berlangsung di kelas. Penggunaan buku Nihongo Kirakira I dapat membantu siswa aktif melalui sesi kegiatan kangaemashou, kite iimashou, dan kikimashou. Sementara sesi yomimashou belum efektif, karena siswa belum lancar membaca huruf hiragana dan katakana. Selain itu, sesi renshuu shimashou ternyata belum dapat memacu keinginan siswa untuk belajar secara mandiri di luar kelas.

Berdasarkan hasil analisis data yang telah dilakukan, diketahui bahwa tanggapan siswa SMA Kesatrian I Semarang terhadap pembelajaran bahasa Jepang menggunakan buku Nihongo Kirakira I secara keseluruhan termasuk dalam kategori tinggi $(65,72 \%)$. Oleh karena itu, dapat disimpulkan bahwa pembelajaran bahasa Jepang menggunakan buku Nihongo Kirakira I dianggap baik oleh siswa SMA Kesatrian I Semarang. 


\section{DAFTAR PUSTAKA}

Effendy, O. U. (2017). Ilmu Komunikasi Teori dan Praktek. Bandung: Rosdakarya.

Haryanto, S. (2012). Belajar dan Pembelajaran. Bandung: Remaja Rosdakarya.

Kurniawan, K. (2012). Belajar dan Pembelajaran Bahasa dan Sastra Indonesia. Bandung: CV Bangkit Citra Persada dengan Jurusan Pendidikan Bahasa dan Sastra Indonesia FPBS UPI.

Prastowo, A. (2014). Panduan Kreatif Membuat Bahan Ajar Inovatif.
Yogyakarta: Diva Press.

Rahayu, P.P. (2019). Analisis Nilai Karakter Yang Terdapat Dalam Buku Nihongo Kira-Kira 1,2 Dan 3. Universitas Negeri Semarang. Widyastuti, C. (2017). Tanggapan Siswa Kelas Vii Terhadap Penggunaan Media Pembelajaran Dalam Pembelajaran Pendidikan Jasmani Olahraga Dan Kesehatan. Universitas Negeri Yogyakarta.

Zainal, A. (2010). Evaluasi Pembelajaran Prinsip, Teknik, Prosedur. Bandung: Remaja Rosdakarya. 